\title{
PERAN PEREMPUAN KAPUK DALAM PEREKONOMIAN SUKU SAMIN TAPELAN
}

\author{
Khoirul Huda dan Anjar Mukti Wibowo \\ Universitas PGRI Madiun \\ khoirulhuda@unipma.ac.id,anjarmuktiwibowo@unipma.ac.id
}

\begin{abstract}
Abstrak
Domestifikasi peran perempuan dalam sektor ekonomi tidak dialami oleh perempuan Kapuk Samin Tapelan Bojonegoro. Meskipun suku Samin dikenal sebagai suku yang memiliki kekhasan adat, partisipasi perempuan dapat ditemukan dalam banyak aktivitas. Riset ini berjenis kualitatif dengan pendekatan studi kasus. Sumber data melaluiwawancara, dan data sekunder analisis dokumendan dokumentasi.Hasil penelitian menunjukkan terdapat tiga bentuk peran perempuan Kapuk dalam sektor ekonomi. Pertama,sektor ekonomi publikutama yaitu berjualan Kapuk dengan sistem ngreyengdan corek.Kedua,sektor publik sekunder adalah dengan memelihara ternak dan berladang, Ketiga,sektor relation-ekonomi dengan wirausaha warung, arisan, dan jualan ayam potong. Peran ekonomi perempuan Suku Samin Tapelan memberikan kontribusi yang signifikan bagi perekonomian keluarga.
\end{abstract}

Kata Kunci: Peran, Perempuan Kapuk, Samin, ekonomi

\begin{abstract}
Female domestification in economic is not the case of female among Samin people in Tapelan, Bojonegoro. Despite Samin's unique culture, their female contributes to economic activities. This is a qualitative research applying case study approach. Sources of data are interview, content analysis and documentation. Results show there are three forms of Kapuk women's role in the public economic sector. The main
\end{abstract}


public sector is selling kapok with ngreyeng and corek systems. The secondary public sector is raising livestock and farming and the latest is economic-relations sector is entrepreneurs, arisan (rotating saving club), and selling chicken. Kapuk woman is a representation of local feminism movement.

Keywords: Role, Kapok Women, Samin, economic

\section{A. Pendahuluan}

Relasi laki-laki dan perempuan dalam kehidupan masyarakat sering menghasilkan berbagai persoalan ketimpangan gender. Perempuan sering mengalami ketidakadilan. Ketidakadilan tersebut akibat adanya anggapan keterlibatan perempuan hanya sebatas pelengkap atau pendamping dalam mensejajarkan dengan laki-laki. Mereka sering mengalami marginalisasi dalam berbagai hal mulai pembagian kerja, pendidikan, ekonomi, dan sebagainya. Ketidakadilan yang dialami perempuan meniscayakan upaya perubahan untuk memperjuangkan hak-haknya sebagai perempuan. Upaya keadilan dan kesetaraan gender dapat dirunut sejak masa awal. Untuk menyebut salah satu, misalnya yaitu R.A. Kartini yang berjuang pada masa pergerakan Indonesia sekitar abad XIX. Chaerunissa (2015: 11-12) menggambarkan peran perempuan masa itu sebagai berikut:

Masa kerajaan terdapat tokoh Ratu Sima (Kalingga) dan Tribhuana Tunggadewi (Majapahit).Masa perjuangan melawan kolonial terdapat beberapa tokoh perempuan yang benar-benar dapat mengangkat senjata melawan kolonial Belanda misalnya Martha Christina Tiahahu, Cut Nyak Din, dan Cut Nyak Meutia.Ada juga tokoh perempuan yang maju ke kancah publik melalui pemikirannya seperti Lasminingrat, Dewi Sartika dan Rohana Kudus.Pada era pergerakan nasional tidak ketinggalan terdapat kongres perempuan sebagai upaya aktualisasi peran perempuan.

Hal ini menandakan bahwa sebelum Indonesia merdeka pun, kaum perempuan telah memperjuangkan mobilitas emansipasi sesuai hak-haknya. Meskipun faktanya masa itu terdapat upaya melepaskan diri dari keterjajahan struktural gender dan memprioritaskan untuk memperoleh pendidikan. Cengkeraman budaya patriarki mengukuhkan anggapan perempuan hanya 
disebut sebagai konco wingking atau pendamping suami yang berada di belakang dan dibebani dengan tugas domestik yaitu masak (memasak), macak (berdandan) serta manak (melahirkan) dan mengurus anak. Peryataan tersebut membatasi perempuan karena faktor fisik dan mental.Dalam dimensi fisik dipandang tidak mungkin melakukan pekerjaan kasar dan keras.

Perempuan mempunyai peran dalam membangun keseimbangan terhadap kaum laki-laki.Namun stigma perempuan dilihat secara fisik lemah sehingga semakin menguatkan pada dimensi perlakuan yang tidak adil. Perempuan sering diperlakukan secara negatif. Kaum perempuan sengaja ditempatkan pada bagian terbatas memiliki ruang gerak bebas. Ruang gerak terbatas termasuk saat mereka bekerja karena mereka membutuhkan pekerjaan sebagai pemenuhan kebutuhan pokok hidup mereka sendiri (Aminah. 2010).Dengan demikian keterlibatan perempuan dalam sektor publik dan rumah tangga menjadi pemandangan yang biasa.

Handayani dan Sugiharti (dalam Widayani dan Hartati, 2014: 154) mengemukakan bahwa perempuan memiliki tiga peran yaitu peran reproduktif, produktif dan sosial. Peran reproduktif dimaknai kemampuan perempuan dalam melahirkan anak,mengasuh dan melakukan pekerjaan rumah tangga yang tidak dipandang bernilai ekonomis sehingga pekerjaan tersebut tidak memberikan pendapatan ekonomi bagi perempuan. Sementara dalam peran produktif, perempuan untuk menempatkan diri pada wilayah publik untuk melakukan kerja yang menjadi sumber pendapatan dan kesejahteraan hidup. Sedangkan peran sosial menyangkut aktivitasnya dalam kegiatan sosial masyarakat. Vitaliya (2010: 145) mendeskripsikan berbagai peran perempuan terkait dengan waktu. Pertama, peran tradisi menempatkan perempuan dalam fungsi reproduksi mengurus rumahtangga, melahirkan dan mengasuh anak, mengayomi suami sehingga pembagian kerja jelas, Kedua, Peran transisi mempolakan peran tradisi lebih utama dari peran lain. Pembagian tugas mengikuti aspirasi gender, tetapi eksistensi mempertahankan kemharminsan urusan rumahtangga tetap perempuan, Ketiga, Dwiperan memposisikan perempuan dalam kehidupan dua dunia yaitu menempatkan peran domestik dan publik dalam posisi sama penting, Keempat Peran egalitarian menyita waktu perempuan untuk kegiatan diluar 
dan kelima Peran kontemporer adalah dampak pilihan perempuan untuk mandiri dalam kesendirian.

Perlakuan tidak adil dalam bidang ekonomi banyak diterima perempuan.Kondisi tersebut juga didorong konotasi masyarakat Jawa yaitu perempuan yang penting menikah, memasak dan melahirkan sehingga peran produktif bukanlah peran adsar perempuan. Bilamana dikaitkan sebagai perempuan Jawa maka cukup kompleks peranannya seperti pendapat Carey (2016: 25) mengemukakan kaum perempuan Jawa dapat menjalankan berbagai peran, mulai pengusaha dan pewaris, pembimbing anak, penjaga tradisi jawa, penunjang agama, penghubung istana dan dunia dan pemelihara pertalian wangsa.

Perihal peran ekonomi perempuan dalam perkembangannya telah bertransformasi sebagai pembangun ekonomi keluarga dalam mencari nafkah. Fenomena ini dapat ditemukan pada kaum perempuan di Suku Samin Desa Tapelan Bojonegoro. Peran ini unik, menilik karakter Suku Samin yang secara umum berpegang teguh pada adat.

Suku Samin merupakan sekelompok masyarakat lokal yang memiliki kekhasan identitas sebagai penganut ajaran Samin Surosentiko. Secara historis mereka mendedikasikan diri sebagai kelompok pejuang menentang penjajah Belanda dipimpin oleh Samin Surosentiko di daerah Blora. Rosyid (2010: 18) membagi empat corak yaitu Sangkak yang jika berinteraksi menggunakan kirotoboso, Ampeng-ampeng perilakunya tidak seperti Samin sejati, Samiroto yang mengaku Samin serba bisa dan menjadi Samin sebenarnya serta dapat mengikuti adat non-Samin, dan Samin dlejet yakni Samin yang berpegang prinsip sebenarnya.

Masyarakat Samin dalam kajian kekinian sering dikonotasikan negatif. Hal ini sebagai akibat dari letak toponimi yang berada di pedalaman dan berperilaku nyeleneh.Padahal Suku Samin memiliki kekhasan unik dan salah satunya adalah Suku Samin Tapelan.Pada umumnya keunikan Samin terletak dari penggunakan gaya bahasa yaitu bahasa jawa ngoko kasar disertai perumpamaan (Purwasito dkk, 2003: 59). Pokok ajaran Samin adalah pertama, agama adalah senjata atau pegangan hidup. Paham Samin tidak membeda-bedakan agama yang penting adalah tabiat hidupnya, kedua 
jangan mengganggu orang, jangan bertengkar, jangan iri hati dan jangan suka mengambil milik orang lain, ketiga sabar dan jangan sombong, keempat manusia harus memahami kehidupan sebab roh hanya satu dan dibawa abadi selamanya, kelima bila orang berbicara harus bisa menjaga mulut, jujur dan saling menghormati dan tidak boleh menerima sumbangan dalam bentuk apapun (Lestari, 2008: 23). Keberadaan Suku Samin juga mengalami perubahan. Soerjanto Sastroamodjo (2003: 31) mengemukakan bahwa kemurnian ajaran kesaminan mungkin hanya bisa bertahan hingga setengah atau paling banter satu abad. Selanjutnya kehidupan mereka mengikuti perkembangan tersebut, misalnya mampu membaur dengan masyarakat, sudah ada penerimaan perubahan-perubahan berupa ilmu pengetahuan maupun teknologi. Hal ini pula yang terjadi di Samin Tapelan Bojonegoro. Keunikan Samin Tapelan adalah terletak pada upaya role taking perempuan melalui peran produktif.

Penelitian ini adalah penelitian studi kasus berjenis kualitatif. Data diperoleh dari informan Kepala Desa, perempuan Kapuk, keluarga atau suami perempuan kapuk, masyarakat di Desa Tapelan. Sumber data primer maupun sekunder dikumpulkan melalui observasi, wawancara dan analisis dokumen. Wawancara menggunakan model terstruktur terhadap beberapa informan yaitu Kepala Desa, Warga Desa untuk memperoleh informasi perkembangan Perempuan KapukTapelan dan Kaum Perempuan Kapuk diperoleh informasi terkait perubahan peran. Sementara model observasi mengggunakan pendekatan partisipasi pasif mengacu pada konsep yang ditawarkan Spradley dalam Prastowo (2012: 199) yang disebut social situation yakni place, actor, danactivities sesuai Tabel 1 .

Tabel 1. Model Realitas Kegiatan Pengamatan Penelitian

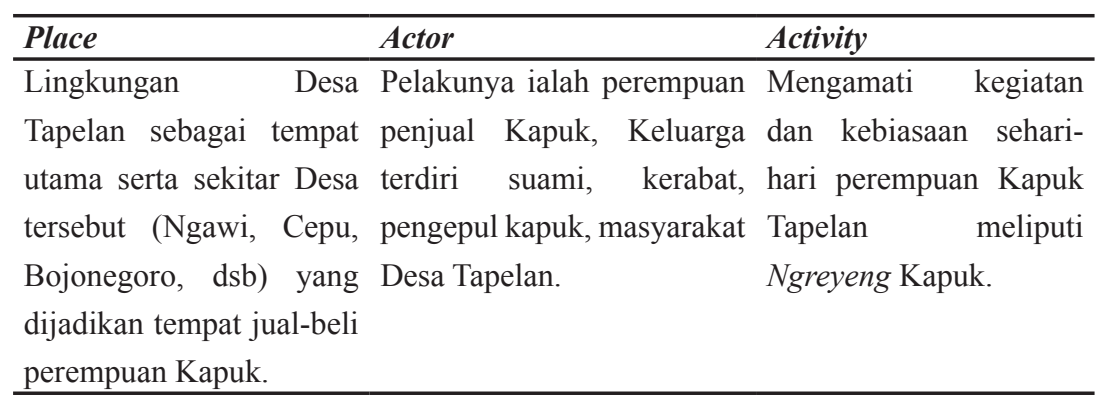




\section{B. Pembahasan}

\section{Keberadaan Suku Samin Tapelan}

Keberadaan Suku Samin Tapelan merupakan salah satu masyarakat dengan kekhasan tersendiri. Di Kabupaten Bojonegoro, masyarakat Samin asli tinggal di daerah Jepang dan Tapelan. Secara historis, aliran Samin berasal dari Surosentiko Samin dari Desa Ploso Kediren Randublatung. Samin Surosentiko atau disebut Surondiko memiliki nama panggilan kecil Raden Kohar. Ajaran yang dianut dari daerah Blora termasuk Tapelan menekankan pada filsafat kebaikan, pengendalian diri dan penguatan perilaku diantaranya membantu orang lain, tidak menyakit orang lain dan harus menjalin kerukunan antar sesama manusia.

Masyarakat Samin Tapelan telah mengalami transisi menuju kategori modern dan mengikuti perkembangan zaman. Saat ini nilai ajaran Samin tidak nampak namun masih terlihat khususnya bagi orang yang pernah mengikuti paham kepercayaan pejuang Samin. Bentuk ajaran tersebut terlihat dari idiom dengan bahasan kiasan seperti ' kita percaya pada neraka dan surga itu pasti di akhirat, tetapi sebenarnya di dunia sudah ada, yaitu penjara bagi mereka yang salah" (wawancara Sugeng, 11 Agustus 2017). Penyesuaian yang dilakukan terhadap perkembangan zaman sangat meningkat dan terjadi alamiah. Namun, persepsi dan stigma negatif masih dilekatkan pada kelompok yang mengikuti ajarannya. Hal ini didorong oleh kuatnya pedoman hidup mereka yang berbeda, juga secara letak geografis yang berada pemukiman terdalam dengan toponimi lahan persawahan, ladang dan tanah kapur (observasi 18 Mei dan 12 Juni 2017).

Saat ini, pengikut ajaran Samin sudah banyak yang meninggalkan dan membangun kehidupan dengan aturan masyarakat. Menurut informasi bahwa yang mengetahui seluk-beluk mata rantai pengikut Samin yaitu Bapak Kasdi (Enton), bahwa Samin Tapelan disebarkan oleh mbah Surokidin dari Dusun Jepang Margomulyo dan 1-2 masih ada di wilayah RW 5 yang dahulu pengikut ajaran Samin.

\section{Dinamika Perempuan Kapuk Suku Samin Tapelan}

Proses dinamika dalam perempuan Kapuk dapat terlihat pada penguatan peran perilaku ekonominya mengingat latar belakang kehidupannya yang 
tergolong sebagai kelompok masyarakat menengah ke bawah. Berdasarkan pengamatan awal yang dilakukan tanggal 18 Mei 2017 bahwa masih banyak dijumpai aktivitas sehari-harinya para perempuan Kapuk dalam mengolah hasil kapuk dari pohon. Aktivitas yang terlihat adalah mereka sedang mengupas buah pohon randu untuk memisahkan antara kulit luar dan isinya berupa kapuk dengan tangan (secara manual) yang sudah dilakukan sejak lama sekitar tahun 1970-an, menjemur sampai tahap pengumpulan kapukkapuk yang sudah dijemur sebelumnya di sebuah tempat yang disebut kebo/ bago. Bago dalam bahasa Jawa berarti wadah untuk menyemai kapuk dan isinya.Kapuk yang telah dijemur selanjutnya dipisah dengan isinya (dalam bahasa Jawa disebut ati) dan kapuk kotor dan kapuk bersih.

Pilihan perempuan Tapelan menjadi pengrajin kapuk dipengaruhi oleh tempat bermukim perempuan kapuk berada di daerah pedalaman yang jauh dari pusat kota, kandungan tanah didominasi oleh lahan kapur, saat ini masih dijumpai beberapa (2-3) tanaman pohon randu, serta lahan tanah yang ditanami jagung, padi dan beberapa tanaman pekarangan seperti ketela dan sebagainya. Terlepas dari hal itu, berdasarkan infomasi yang diperoleh dari informan yakni Ninik Herna Kustanti (wawancara 10 Juli 2017) menyebutkan bahwa rata-rata perempuan yang menjual kapuk adalah dari golongan tua seperti ibu-ibu rumah tangga.Kondisi tersebut mengasumsikan bahwa perempuan yang tergolong remaja kurang terlibat aktif pada profesi ini, namun ditemukan sebagian meneruskan pekerjaan orang tua sebagai penjual kapuk bahkan kadang juga diajak ikut berjualan (ngreyeng kapuk).

Memudarnya keinginan perempuan muda Tapelan untuk berprofesi sebagai perempuan Kapuk, dipengaruhi oleh profesi lain yang lebih menjanjikan seperti bekerja sebagai buruh tani atau di luar kota. Menurut Sutrisno (wawancara 10 Juli 2017), daerah Tapelan terkenal dengan para perempuan yang menjual kapuk, tetapi saat ini yang masih bertahan dari kalangan ibu-ibu yang telah berusia tua karena dipengaruhi oleh kebutuhan hidup dan ekonomi.

Daerah Tapelan terkenal dengan perempuan penjual Kapuk, ditandai dengan kedatangan P ak Prio (mbah Prio) sekitar tahun 1965-1966 dan 1970-an dari Madiun. Pak Prio aslinya adalah seorang pengusaha kapuk pada 
waktu itu. Sekitar tahun tersebut, area lahan daerah Desa Tapelan memang banyak tumbuh pohon kapuk randu.Waktu itu oleh mbah Prio dibuatkan gudang khusus untuk kapuk untuk para tengkulak atau masyarakat sekitar yang akan menjualnya dan mengandalkan alat transportasi truk sebagai mode angkutan kapuk. Pada rentang tahun tersebut, area lahan pohon Randu di daerah Tapelan sangat dominan. Kedatangan Pak Prio yang menjadi cikal bakal pekerjaan mengolah kapuk yang dahulu membuat gudang khusus kapuk sehingga berdampak di aktivitas perekonomian masyarakat. Namun, seiring perkembangan waktu, lama-kelamaan gudang kapuk yang dijual macet karena zaman semakin berkembang sehingga kalah bersaing dengan perkembangan busa atau para tengkulak yang lain sebab berani mematok harga rendah. Kemerosotan industri kapuk di desa Tapelan juga disebabkan oleh kelangkaan pohon randu sendiri sebab banyak ditebang. Alasannya adalah untuk menekan dan mengurangi kekhawatiran,bahaya serta ketakutan masyarakat akan kejatuhan pohon randu mengingat seringkali buah kapuknya jatuh di atas genteng atau halaman rumahnnya.

Dinamika industri kapuk di Tapelan berpengaruh pada terdapat perubahan cara usaha para perempuan menjual kapuk. Jika dalam rentang tahun 1990-1999 menjual kasur dan kapuknya, kemudian sekitar tahun 1999 mereka mulai ngreyeng untuk menjual kapuk hingga sekarang ini. Faktor yang mempengaruhi perubahan tersebut sebab banyak saingan produksi atau pasokan kapuk terutama dari daerah Kendal, Madiun dan Solo.

Menurut informasi, saat ini perempuan penjual kapuk yang masih bertahan sekitar 50-an orang tersebar mulai dari beberapa RT seperti RT 8 sebanyak 10 orang, RT 9 sebanyak 20 orang, RT 10 sebanyak 10 orang dan RT 11 sebanyak 10 orang (Wawancara Sugeng, 11 Agustus 2017). Selain itu, yang bekerja menjual kapuk perempuannya, sedangkan suaminya dirumah. Hal ini berdasarkan informasi dari Ibu Samto (wawancara, 10 Juli 2017) mengatakan bahwa rata-rata perempuan kapuk ini berstatus sebagai istrinya dimana sedangkan sang suami sering di rumah. Mereka menjual kapuknya dengan keliling ke berbagai daerah ada yang ke Ngawi, Madiun, Caruban, Lamongan yang seringkali harus meninggalkan rumah dalam jangka waktu seminggu atau paling cepat 1-2 hari baru pulang. Selama para perempuan 
kapuk bekerja ke luar kota, maka peran laki-laki untuk mengurus pekerjaan rumah tangga dan mengurus pendidikan anak. Mereka bekerja secara serabutan sehingga penghasilannya tidak menentu.

Bagi masyarakat Tapelan, laki-laki sebagai kedudukan laki-laki sebagai penanggungjawab dan penopang ekonomi keluarga, digantikan atau dibantu oleh istrinya (perempuan)sering bekerja. Para perempuan kapuk Tapelan pun menjadi penguat ekonomi keluarga. Penghasilan yang mereka dapatkan sebagai ngreyeng kapuk masih belum mencukupi untuk kebutuhan sehariharinya.Penghasilan dari ngreyeng kapuk selama beberapa hari jika terjual rata-rata antara Rp.20.000-Rp.50.000 belum cukup untuk meningkatkan ketercukupan keluarga.Mata pencahariaan lainnya pun hanya dengan menjadi buruh tani, berladang dengan menanam jagung dan memelihara ternak ayam, sapi atau kambing.

Lesunya penjualan kapuk didorong oleh beberapa faktor diantaranya Pertama, sempitnya lahan pertanian yang saat ini didominasi oleh sawah TKD (Tanah Kas Desa), Kedua dimusnahkannya pohon randu sebagai penghasil bahan baku kapuk yang menurut informasi alasan dipotong (ditebang) karena lahan area kapuk membahayakan masyarakat sekitar sehingga mayoritas banyak harus beli di tengkulak sekitar 4-5 tahun terakhir, dan Ketiga pemasaran sulit karena kalah bersaing dengan produk kasur busa dari Paciran dan harganya lebih murah, perbandingannya harga kasur busa Paciran (Bojonegoro) adalah Rp. 750.000 sedangkan kasur kapuk dengan ukuran 65 M x 2 M dan Tinggi 20 M seharga Rp. 900.000.

Perkembangan dan dominasi kasur busa dan springbed di tengahtengah konsumen lebih meningkat dibandingkan dengan kasur kapuk. Meskipun demikian, demi ekonomi dan kebutuhan keluarga yang cukup, maka perempuan penjual kapuk dari desa Tapelan bertahan hingga sekarang. Mereka memilih bertahan karena lapangan kerja sempit dan tidak ada pengalihan pekerjaan yang menetap yang sesuai dengan mereka, jauhnya jarak tempat tinggal mereka dengan pusat kota sehingga mempengaruhi minimnya variasi lapangan kerja, dan bilamana ingin membuka usaha lain seperti warung akan kalah bersaing karena pusat kota telah menjamur usahausaha seperti itu. 
Dengan demikian, perubahan peran perempuan kapuk di daerah Tapelan apabila dikaji dalam feminisme ekonomi mampu menempatkannya dalam kebebasan mobilitas.Perempuan kapuk Samin Tapelan di dalam perkembangannya sampai saat ini mempunyai keleluasaan untuk mobilisasi yang ditunjukkan dengan peralihan peran gender.Mereka telah mengubah tradisi patriarki dari sebelumnya yang diantaranya untuk tidak boleh berjualan (jualan di pasar) yang merupakan tuntutan pedoman yang memiliki paham ajaran Samin sehingga bertransformasi menuju kebebasan dan memiliki kesetaraan dengan akses publik dengan kaum laki-laki.

\section{Bentuk Peran Perempuan Kapuk Dalam Feminisme Kontemporer}

Secara prinsip bentuk peranan perempuan kapuk dalam menunjang penghasilan perekonomian keluarga sama sepertiyanglain dengan diwujudkan dalam model peran sebagai ibu rumah tangga (domestik) dan bekerja di luar (publik). Tidak semua peranan di keluarga dalam berbagai kegiatan mulai dari kegiatan rumah tangga di pagi hari atau ketika sudah pulang bekerja.Kegiatan tersebut dilakukan sebelum mereka bekerja dan kebiasaaan ini dilakukan bersama-sama dengan anggota keluarga, namun intensitas kegiatan yang dilakukan waktunya masih sedikit karena mereka harus melanjutkan roda perekonomian dengan menjual kapuk. Namun apabila mereka tidak bekerja, maka peran perempuan melakukan pekerjaan rumah seperti kegiatan rumah tangga misalnya mencuci, memasak, mengurus anak sekolah atau memelihara ternak. Menurut Sulikah bahwa kegiatan selain menjual kapuk sama seperti pekerjaan rumah tangga, tetapi bila sudah ngreyeng, maka pekerjaan rumah sejak pagi sudah dikerjakan kemudian baru berangkat (wawancara, 11 Agustus 2017). Dengan demikian peran perempuan secara ekonomi terlihat nyata dalam keluarga. Eksistensi perempuan Kapuk di Desa Tapelan ikut menjadi penguat dalam meningkatkan pendapatan dengan berjualan kapuk dan sarung kasur. Untuk akses jualannya dilakukan dengan menawarkan ke daerah lain.

Banyak dijumpai aktivitas sehari-harinya perempuan Desa Tapelan dengan menjual kapuk pahon randu. Mulai pagi pukul 08.00-10.30 WIB mereka sudah berangkat ngreyeng kapuk dengan waktu ngreyeng kapuk ada yang 1-2 hari pulang, 1 minggu bahkan 1 bulan baru pulang. Mereka 
berbondong-bondong jalan kaki secara kelompok ke daerah pinggir jalan Ngori untuk menunggu bus.

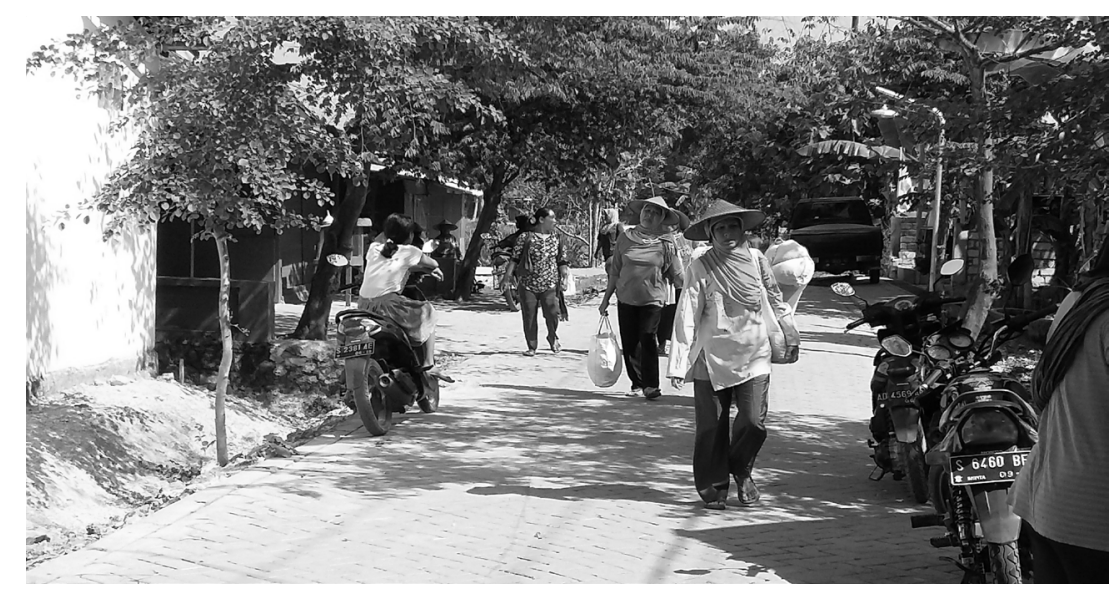

Gambar 1. Para Perempuan Kapuk dari Desa Tapelan Berangkat Kerja

Berkenaan dengan hal tersebut, terbentuknya relasi baru status dan peran akibat dari ibu-ibu di Tapelan mengambil fungsi sebagai penguat utama ekonomi keluarga dengan menjual kapuk, sedangkan laki-laki (suaminya) di rumah dengan mata pencahariaan seadanya dan tidak menentu. Peralihan dan perubahan peran ekonomi mampu membawa pada mobilitas yang sudah tidak terikat oleh budaya masyarakat tradisional (patrilineal). Budaya peralihan tersebut menawarkan internalisasi berpikir yang sudah maju sehingga tidak tergantung lagi pada dominasi kaum laki-laki.Suharno menyatakan bahwa sekarang ini telah ada kecenderungan keterbukaan budaya yang dari sumbernya telah memudar atau terbentuk open culture (2013: 4).Keterbukaan budaya ditandai terhadap suatu peralihan fungsi,peran, dan tugas pokok perempuan kapukdi Tapelan dalam hal ekonomi terutama keleluasaan bekerja. Kerangka perubahan peran perempuan Kapuk sebagai status ganda dalam kehidupannya, mengharuskan dan memaksanyauntuk berada pada keterbatasan mobilitas yang bebas.

Secara hierarki konsep peran perempuan kapuk dalam meningkatkan pendapatan bidang perekonomian terutama dalam sektor publik dapat dikategorikan tiga bagian, yaitu pertama, sektor ekonomi publik utama. Kategori ini dari kebutuhan perekonomian utama adalah dengan ngreyeng 
(menjual) kapuk. Pada prinsipnya alasan yang yang mendasari kaum perempuan untuk menjual kapuk adalah pertama, lahan pertanian makin sempit karena banyak lahan sawah milik TKD (Tanah Kas Desa) sehingga masyarakat merasa berat dan terbebani, dan ketiga adalah sumber daya manusia kategori minim karena banyak perempuan (masyarakat) Tapelan umumnya pada tingkat SD sampai SMA.Bagaimana kaum perempuan kapuk di Desa Tapelan mengolah kapuk dari pohon randu mulai dari kapuk wungkul, memisahkan kulit dan bijinya, menjemurhingga menjadi serat kapuk bersih atau kapuk kotor dengan mencampurkan ati kapuknya.Sistim penjualan Kapuknya adalah dengan ngreyeng dan corek. Ngreyeng adalah cara penjualan yang dilakukan oleh kaum ibu-ibu penjual Kapuk Desa Tapelan dengan berkeliling keluar daerah-daerah untuk menawarkan produk kapuknya dan biasanya sampai menginap beberapa hari, bisa 1-2 hari, seminggu atau sebulan baru pulang. Hal ini yang oleh masyarakat Tapelan disebut corek yang artinya adalah budal isuk muleh sore (berangkat pagi pulang sore) dan perolehan hasil jual tidak pasti. Ketika pulang, bilamana kapuk belum laku akan dititipkan masyarakat sekitar di daerah tempat ngreyeng tersebut.

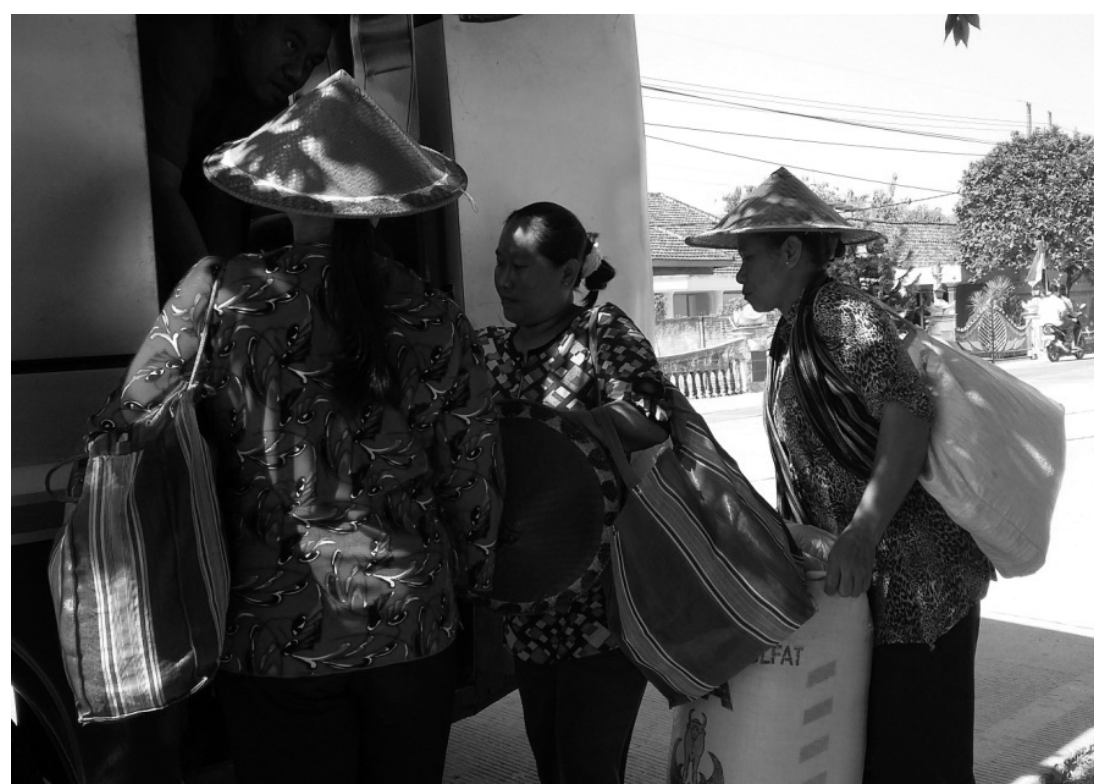

Gambar 2. Perempuan Kapuk Berangkat Ngreyeng menuju daerah Padangan, Blora, Cepu atau Lamongan 


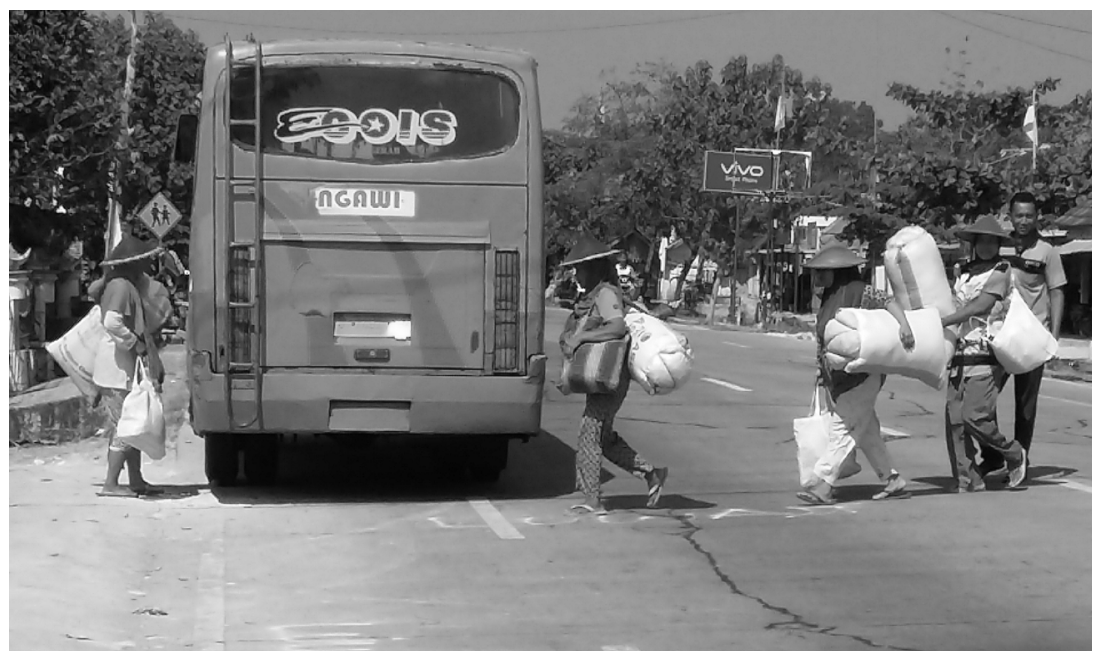

Gambar 3. Perempuan Kapuk Berangkat Ngreyeng menuju Ngawi dan sekitarnya.

Hasil pendapatan yang diperoleh pun juga tidak menentu karena saat ini harus bersaing dengan kasur jenis busa yang berasal dari Paciran dan Bojonegoro serta Springbed yang sangat banyak diminati oleh para konsumen. Berbeda dengan dahulu sekitar tahun 1970an sampai 1999an yang masih ramai peminat karena produksi kasur busa masih belum meningkat signifikan seperti sekarang ini. Penurunan penghasilan ini disebabkan beberapa faktor. Pertama, Persaingatan ketat dengan produk yang lebih modern yaitu kapuk busa atau springbed. Kedua, mulai 4-5 tahun terakhir, bahan baku kapuk harus beli dari pengepul kapuk (tengkulak). Ketiga, para konsumen lebih mempunyai minat yang tinggi terhadap jenis kasur busa atau spingbed dari pada kasur yang terbuat dari kapuk.

Untuk harga jual kapuk per 1 kg sekitar Rp. 25.000-Rp. 35.000 dengan pendapatan kotor mulai Rp. 35.000-Rp.50.000. Ada yang menyebutkan pula bahwa bila penghasilan mateng (bahasa masyarakat Tapelan penjual kapuk) bisa mendapatkan pendapatan mulai 20.000 hingga maksimal Rp. 50.000.Dari penghasilan tersebut digunakan untuk kebutuhan sehari-hari dan keluarganya meskipun dikategorikan cukup.Peningkatan kebutuhan ekonomi sampai sekarang ini masih bergantung kepada ibu-ibu yang menjual kapuknya meskipun dengan persaingan pasar yang sangat besar dengan pengusaha kasur busa atau springbed. 
Hampir semua ibu-ibu dari beberapa RT di RW 02 seperti RT 8 (10 orang), RT 09 (20 orang) RT 10 (10 orang), dan RT 11 (10 orang) pada bekerja sebagai penjual Kapuk sejak dahulu yang diperkirakan sekitar Tahun 1965an. Daerah jualnya merentang dari Jawa Tengah dan Jawa Timur. Mereka berkeliling ke Pati, Gondosuli, Blitar, Pandaan, Ngambon, Gresik, Lamongan, Blora, Surabaya, Magetan, Ponorogo, Paciran (Bojonegoro), Jepon, Purwodadi, Maospati, Caruban dan Babat. Sedangkan, kaum lakilaki (suami)dari perempuan penjual kapuk rata-rata bekerja serabutan dengan pendapatannya tidak tetap (musiman).Mata pencahariaan tersebutd iantaranya sebagai buruh tani dengan penghasilan (musiman) Rp. 50.000, sekrop pasir (mencari pasir)dan sekrop tambang di daerah Jawa Tengah (jika musim kemarau sepi), nyuloh (mencari) katak dan bekicot untuk dijual di daerah Bojonegoro, serta tiga tahun terakhir sudah mulai ada yang kerja di Papua atau Kalimantan untuk menjadi kuli bangunan.

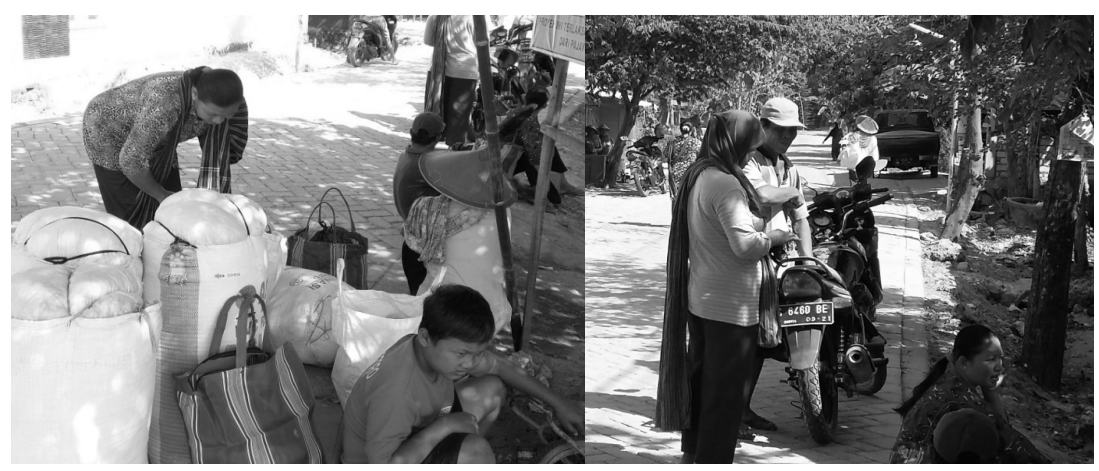

Gambar 4. Perempuan Kapuk berkumpul di Ngori dengan kelompok Ngreyengnya
Gambar 5. Perempuan Kapuk dan suaminya yang sedang mengantar untuk berangkat Ngreyeng

Beberapa bentuk peranan tersebut membuat posisi mereka yang berkaitan dengan kebutuhan ekonomi keluarga menjadikan tanggung jawab cukup berat oleh kaum perempuan penjual kapuk dalam mencari nafkah. Mereka cenderung pasrah dan menerima dengan penghasilan yang harus disesuaikan dengan kebutuhan keluarga. Ketidakidealan ini akan memicu perubahan perempuan untuk bergerak pada kondisi peran sub-altern terutama kewajiban perempuan sebagai anggota keluarga dan masyarakat yang 
seharusnya tidak bisa di tanggung semua. Situasi dan kondisi keterbatasan kebutuhan yang mendorong mereka dalam keterpaksaan untuk bekerja sebagai penjual kapuk.Meskipun perihal tersebut tidak selalu menjadi faktor utama, tetapi menilik dari perkembangannya kondisi sumber daya alam dan manusia juga ikut berperan mendorong kegiatan ranah publik.

Keterbatasan sumber daya manusia serta kondisi geografis mendorong untuk memilih bermata pencahariaan tersebut. Para perempuan penjual kapuk karena seringkali harus berkeliling menjajakan kasur, maka intensitas waktu untuk berkumpul dengan keluarga menjadi berkurang. Pengasuhan anak yang oleh masyarakat biasanya dilakukan oleh ibu, beralih kepada nenek, saudara atau ada yang diajak ikut untuk ngreyeng kapuk. Dengan demikian, profesi penjual kapuk bagi kaum perempuan desa Tapelan, secara kultural, peran pengasuhan anak dan ibu rumah tangga tetap dibebankan kepada mereka.

Kedua, sektor ekonomi publik sekunder adalah merupakan bagian dari upaya meningkatkan pendapatan ekonomi yang dilakukan oleh kaum perempuan kapuk Desa Tapelan untuk memperoleh penghasilan tambahan selain pekerjaan pokok sebagai penjual kapuk. Mata pencahariaan ini biasa disebut pekerjaan pendukung (sampingan)yang dapat dinikmati dalam jangka panjang untuk keperluan tak terduga.Pekerjaan sampingan tersebut diwujudkan dengan memelihara ternak dan berladang.Umumnya beternak hanya sebatas dalam memelihara sapi, kambing dan ayam yang bila diperlukan atau ada yang membutuhkan akan dijual.Selanjutnya, mata pencahariaan yang lain adalah berladangdengan menanam jagung dan menanam padi. Wilayah desa Tapelan memiliki lahan ladang dengan luas $4 \mathrm{Ha}$, belum termasuk lahan lainnya sekitar 127 Ha yang umumnya ditanami Jagung. Selain itu, beberapa perempuan kapuk juga pernah ikut menanam padi di sawahnya milik Negara atau Tanah Kas Desa (TKD).

Ketiga, sektor relation-ekonomi adalah merupakan suatu usaha aktivitas ekonomi yang dilakukan oleh ibu-ibu penjual kapuk yang tidak tetap dan untuk mencukupi sektor ekonomi utama dan sekunder. Kegiatan ini mirip dengan usaha sampingan namun pembedanya adalah dari sifat aktivitasnya yang dominan dengan relasi publik yang terdapat situasi 
interaksi antara orang lain secara intensif selama kegiatan berlangsung. Kegiatan perekonomian tersebut dalam beberapa bentuk diantaranya adalah warung, arisan, dan jual ayam potong. Usaha warung tersebut pernah dilakukan namun hanya beberapa waktu saja dan jumlahnya tidak banyak yang berdasarkan pengamatan terdapat dua atau tiga warung.Warung tersebut biasanya sebagai menjual kopi, gorengan dan rokok. Hanya saja warung tersebut ramainya hanya musiman seperti ketika adanya panen raya. Mereka kalah bersaing dengan keberadaan warung atau toko di pinggir jalan yang menawarkan fasilitas yang lebih memadai.Untuk kegiatan lingkungan sama seperti biasanya yaitu dengan ikut arisan Rukun Tetangga (RT) sebulan sekali dan kegiatan arisan muslimatan setiap hari Jum ’at sekitar Rp. 10.000 di Masjid Baiturahim Tapelan. Belakangan mereka juga mencoba untuk usaha lain yaitu dengan menjual ayam potong di pasar kira-kira antara 5-6 potong ayam, akan tetapi ngreyeng kapuk masih tetap prioritas.

Berdasarkan beberapa penjelasan informasi tersebut, maka apa yang dilakukan perempuan Kapuk merupakan suatu perjuangan hidup bagi mereka saat ini yang didorong situasi dan kondisi yang diterima sebagai kelas ekonomi menengah ke bawah. Adanya pergesaran peran strategis ekonomi sebagai suplay pendapatan utama menjadikan keterbebanan dan kepasrahan secara psikologis membuat kaum perempuan kapuk Suku Samin di Tapelan mau tidak mau merasa mempunyai tanggung jawab yang tinggi. Para perempuan Kapuk menganggap peranannya sebagai pemelihara, penanggung jawab dan pengatur rumah tangga.Keadaan seperti itu berdampak pada pembagian peran dalam kehidupan keluargayang mana kaum perempuan harus bekerja dan berpikir untuk mengontrol kesejahteraan ekonomi keluarga.

Kondisi realita tersebut dapat mempertegas bahwa di era postmodernisme masih dijumpai role taking dalam bidang ekonomi keluarga. Maka nilai-nilai feminisme tersebut juga perlu mendapat perhatian untuk generasi saat ini terutama peserta didik agar dapat menginternalisasi perjuangan seseorang bagaimana usaha-usaha untuk mencapai kesejahteraan hidup yang lebih baik. Spirit para perempuan kapuk di desa Tapelan dalam berjuang untuk terus mencapai suatu hal yang lebih baik dan sukses serta nilai-nilai tanggung jawab dan ketekunan. 


\section{Simpulan}

Dinamika perempuan Kapuk Tapelan menunjuk pada role taking (pengambilan peran), tugas dan tanggung jawab laki-laki dalam ekonomi keluarga.Peralihan tersebut merupakan suatu bentuk mobilisasi kaum perempuan untuk berkontribusi dalam peran utama ekonomi keluarga .Ada tiga bentuk peran perempuan Kapuk Tapelan dalam meningkatkan pendapatan perekonomian di sektor publik. Pertama, yang bersifat utama dengan cara berjualan kapuk melalui sistim ngreyengdan corek. Kedua, sektor ekonomi publik sekunder adalah mata pencaharian pendukung dengan memelihara ternak dan berladang. Ketiga, sektor relation-ekonomi adalah usaha yang dilakukan penjual kapuk yang tidak tetap diantaranya dengan warung, arisan, dan jual ayam potong.

\section{DAFTAR PUSTAKA}

Hubeis, Aida Vitayala, 2010, Pemberdayaan Perempuan Dari Masa Ke Masa. Bogor: IPB Press

Anirah, Andi, 2012, "Peran Strategis Perempuan Dalam Masyarakat" dalam Musawa, Vol. 4 No.1Juni 2012, hal.45- 58

Purwasito, Andrik,2003, Agama Tradisional: Potret Kearifan Hidup Masyarakat Samin Dan Tengger. Yogyakarta: LKiS

Wahyuningsih, Fahmi, 2013, "Perjuangan Tokoh Emansipasi Perempuan Indonesia Dan Jerman” dalam Lentera Jurnal Studi Perempuan. Volume 9 Nomor 1 Juni 2013 hal. 48-55.

Hanum, Farida, 2011, "Peran Wanita Dalam Membangun Masyarakat Berkeadilan Gender” dalam Jurnal Sosiopublika. Volume 1 Nomor 1 Oktober 201 hal. $75-85$

Sutopo, H.B, 2006, Metodologi Penelitian Kualitatif, Surakarta. Universitas Sebelas Maret. 
Aminah, Mia Siti, 2010, Muslimah Career Mencapai Karir Tertinggi Dihadapan Allah, Keluarga, Dan Pekerjaan, Yogyakarta: Pustaka Gratama.

Miles Dan Huberman, 1992, Analisis Data Kualitatif. Terjemahan Oleh Tjetjep Rohendi Rohidi. 2009. Jakarta : Universitas Indonesia.

Rosyid, Mohammad, 2010, Kodifikasi Ajaran Samin, Yogyakarta: Kepel Press

Teguh, Muhammad, 1999, Metodologi Penelitian Ekonomi Teori Dan Aplikasi, Jakarta: PT. Rajagrafindo Persada.

Widayani, Ni Made Diska Dan Sri Hartati, 2014, “ Kesetaraan Dan Keadilan Gender Dalam Pandangan Perempuan Bali: Studi Fenomenologis Terhadap Penulis Perempuan Bali” dalam Jurnal Psikologi UNDIP Volume 13 Nomor 2 Oktober 2014 hal. 149-162.

Carey, Peter Dan Vincent Houben, 2016, Perempuan-Perempuan Perkasa Di Jawa Abad XVIII-XIX. Jakarta: Gramedia.

Lestari, Puji, 2008, "Analisis Perubahan Sosial Pada Masyarakat Samin (Studi Kasus Di Desa Mendenrejo Kecamatan Kradenan Blora” dalam Dimensia. Volume 2 Nomor 2 September.

Seprina, Reka, 2013, "Pengembangan Pembelajaran Sejarah Lokal Berbasis Media Animasi Untuk Meningkatkan Kesadaran Budaya Siswa SMP N 1 Surakarta” Tesis. Solo: Pascasarjanan UNS.

Sastroatmodjo, Soerjanto, 2003, Masyarakat Samin: Siapakah Mereka?. Yogyakarta: Narasi.

Soekanto, Soerjono, 2010, Sosiologi Suatu Pengantar. Jakarta: PT Raja Grafindo Persada.

Priyadi, Sugeng, 2012, Sejarah Lokal: Konsep Metode Dan Tantangannya. Yogyakarta: Ombak.

Suhartono, 2010, Teori Dan Metodologi Sejarah, Yogyakarta: Graha Ilmu.

Silalahi, Ulber, 2010, Metode Penelitian Sosial, Bandung: PT Refika Aditama

Chaerunisa, Yasmin Nindya, 2015,"Konstruksi Pembelajaran Sejarah Yang Berorientasi Pada Kesetaraan Gender: Kajian Naturalistic Inquiry Di Kelas XI IPS B SMA Neberi Bandung” Tesis. UPI Bandung. 